Bangladesh J. Bot. 48(4): 951-956, 2019 (December)

\title{
MORPHOLOGY AND PIGMENT CONTENT OF SPOROPHYTES AND GAMETOPHYTES OF TEN FERN SPECIES
}

\author{
Asia Bibi*, Shabbir Ejaz, Sidra Rafique and Saima Ashraf \\ Department of Botany, Women University of Azad Jammu and Kashmir, \\ Bagh-12460, Pakistan
}

Keywords: Sporophyte, Gametophyte, Pigment contents, Morphology

\begin{abstract}
The morphology and pigment contents of sporophytes and gametophytes of ten fern species were studied. In the morphological study, variations were found in stipe, texture, rachis, fronds and sori of these species. Photosynthestic pigment contents of sporophyte and gametophyte of ten species vary to a great extent. Even sporophyte and gametophyte of same species vary in pigment content. Sporophyte revealed higher chlorophyll content than gametophyte. The highest chlorophyll $a$ and $b$ were found in the gametophyte of Cetarach officinarum Gametophyte of Adiantum flabellatum produced maximum anthocyanin whereas minimum anthocyanin content was found in the sporophyte of Cetarach dalhousiae. The highest carotenoid content was obtained from the gametophyte of Cheilanthus albomarginata. Altitudinal variations were also found to affect morphology and pigment content of sporophytes and gametophytes of ten fern species.
\end{abstract}

\section{Introduction}

Pteridophytes are evolutionally, in a pivotal position between bryophytes and seed plants (Pryer et al. 2001). A characteristic that distinguishes pteridophytes from other land plants is their independent sporophyte and gametophyte generations. Gametophytes of fern live on substrate surfaces as small individual plants and have no vascular system. However, sporophytes of ferns possess a vascular system that enables them to grow more than gametophytes that results in a large herbaceous plants (Wada 2007). It has been suggested that the distribution of ferns is mostly determined by factors of climate and habitat due to relatively low limitations in ferns for dispersal and establishment (Wild and Gagnon 2005). Many species are able to change the composition of their photosynthetic apparatus to optimize photosynthesis for the light environment in which they are growing. Chlorophylls play a very important role in photosynthesis; plants have additional pigments that participate in photosynthesis. Chlorophyll $a$ and chlorophyll $b$ show controlled changes in adapting to various growth conditions, enabling optimal utilization of available light. It is known that the chlorophyll $a$ to $b$ ratio is higher in high-light growth conditions than in lowlight growth conditions. Thus the regulation of chlorophyll $b$ synthesis is important for understanding the mechanisms of adaptation of plants to various light intensities. Other pigments that occur in plants are xanthophylls and carotenes (Taiz and Zeiger 2002). Though a lot of information is available about the photosynthesis and respiration of flowering plants but information about fern plant is meager. Hence, present project was undertaken to determine qualitative variations in the morphology of ten selected fern sporophytes belonging to same order and to measure photosynthetic pigment contents in ferns sporophytes and gametophytes.

*Author for correspondence: <wellwisher.ajk@gmail.com> 


\section{Materials and Methods}

Ten species of ferns viz. Adiantum capillus-veneris (L), A. caudatum (Linn.), A. fimbriatum Christ, A. flabellatum L., A. incisum, A. venustum (Don) L., Asplenium trichomanes (L), Ceterach dalhousiae Hook, C. officinarum Willd, Cheilanthus albomarginata (Clarke) belonging to order Filicales were collected from District Muzaffarabad, Azad Kashmir according to randomized complete block design (RCBD) with four replicates. Experimental work was carried out in the laboratory, Department of Botany, University of Azad Jammu and Kashmir, Muzaffarabad. After morphological observations of the sporophyte, both sporophyte and gametophyte were subjected to measure pigment contents according to Arnon (1949). All the quantitative data obtained were subjected to analysis of variance (ANOVA) and then LSD at $\mathrm{p} \leq 0.05$ was performed to compare the variations.

\section{Results and Discussion}

The morphology of ten fern species were studied and lots of variations were observed in the stipe, texture, rachis, fronds and sori of these species. Stipe of Adiantum capillus-veneris was found selender and suberect, A. caudatum tufted and wiry, A. flabellatum, A. fimbriatum and Asplenium trichomanes brown, dark brown and dark brown to dark purple, respectively. Adiantum incisum and A. venustum have proximate and hairy stipe while the stipe of Cetarach dalhousiae and C. officinarum was broad and lancolate. Cheilanthus albomarginata have smooth stipe and without any kind of scales.

Many variations were observed in the texture of studied ferns sporophyte. Sporophyte of Adiantum capillus-veneris, A. fimbriatum, A. flabellatum, A. incisum and Cheilanthus albomarginata was thin and herbaceous. Glabrous texture was observed in Adiantum venustum, Asplenium trichomanes and Cetarach dalhousiae whereas Cetarach officinarum and Adiantum caudatum revealed glossy and villose texture, respectively.

Rachis of Adiantum capillus-veneris was naked, of Adiantum caudatum with sparsely placed pinnae and of Adiantum fimbriatum, A. flabellatum, A. incisum and A. venustum with deltate, pinnate extended, hairy and petiolate, respectively. Asplenium trichomanes, Cetarach dalhousiae and Cetarach officinarum were found to have glabrous rachis whereas the rachis of Cheilanthus albomarginata was smooth.

Frond, the special characteristic of ferns bears sporangia at maturity. Very little variations were observed in the physical appearance of fronds of the studied fern species. Almost all the studied fern species were found to have pinnately compound fronds. Fronds of Adiantum capillusveneris were bipinnate with short terminal pinnae and of Adiantum caudatum were villose and pinnately compound. Adiantum fimbriatum was found having asymmetricaly pinnate fronds and Adiantum flabellatum with pinnate fronds. Adiantum incisum, A. venustum and Asplenium trichomanes possessed pinnate, pinnately compound, pinnate linear lanceolate type fronds, respectively. Fronds of Cetarach dalhousiae were long glabrous, lanceolate and pinnately compound whereas of Cetarach officinarum and Cheilanthus albomarginata were pinnate with trichome and pinnate deltate, respectively.

Sori of Adiantum capillus-veneris were roundish, of Adiantum caudatum transversely oblong, of Adiantum fimbriatum, A. flabellatum, A. incisum, A. venustum and Asplenium trichomanes were indusiate. Cetarach officinarum possessed exindusiate sori whereas sori of Cheilanthus albomarginata were indusiate marginal.

In pteridophytes, chlorophyll content is both quantitatively and qualitatively similar to that of higher plants. Gametophyte generation is essential in the fern life cycle, however, very little is known about its ecology and physiology (Watkins et al. 2007). The photosynthetic pigments vary 
from same species from different habitats. Photosynthetic pigments were determined from the sporophyte and gametophyte of ten selected fern species belonging to order Filicales and significant variations were observed in them. Sporophytes and gametophytes of same fern species vary in pigment contents. Decrease in pigment contents was observed from all the studied fern species from sporophyte compared to gametophyte. Gametophyte of the Cetarach officinarum revealed maximum chlorophyll $a$ significantly followed by Adiantum flabellatum whereas minimum chlorphyll $a$ was observed from sporophyte of Adiantum caudatum (Fig. 1).

Table 1. Morphological parameters of ten ferns belonging to order Filicales.

\begin{tabular}{|c|c|c|c|c|c|c|c|}
\hline & Species & $\begin{array}{l}\text { Altitude } \\
\text { (Feet) }\end{array}$ & Stipe & Texture & Rachis & Fronds & Sori \\
\hline 1 & $\begin{array}{l}\text { Adiantum } \\
\text { capillus-veneris } \\
\text { (L) }\end{array}$ & 4900 & $\begin{array}{l}\text { Suberect rather } \\
\text { slender }\end{array}$ & $\begin{array}{l}\text { Pellucid } \\
\text { herbaceous, } \\
\text { thin }\end{array}$ & Naked & $\begin{array}{l}\text { Bipinnate with } \\
\text { short terminal } \\
\text { pinnae }\end{array}$ & Roundish \\
\hline 2 & $\begin{array}{l}\text { A. caudatum } \\
\text { (Linn) }\end{array}$ & 4860 & Tufted, wiry & Villose & $\begin{array}{l}\text { Sparsely } \\
\text { placed } \\
\text { pinnae }\end{array}$ & $\begin{array}{l}\text { Pinnately } \\
\text { compound, } \\
\text { villose }\end{array}$ & $\begin{array}{l}\text { Transversely } \\
\text { oblong }\end{array}$ \\
\hline 3 & $\begin{array}{l}\text { A. fimbriatum } \\
\text { Christ }\end{array}$ & 8250 & Dark brown & $\begin{array}{l}\text { Thin, } \\
\text { herbaceous }\end{array}$ & deltate & $\begin{array}{l}\text { Asymmetrical } \\
\text { pinnate }\end{array}$ & Indusiate \\
\hline 4 & A. flabellatum L. & 3900 & Brown, hairy & $\begin{array}{l}\text { Herbaceous, } \\
\text { slightly } \\
\text { striate }\end{array}$ & $\begin{array}{l}\text { Pinnate, } \\
\text { extended }\end{array}$ & Pinnate & Indusiate \\
\hline 5 & A. incisum & 4750 & Proximate & $\begin{array}{l}\text { Herbaceous, } \\
\text { slightly } \\
\text { striate }\end{array}$ & Hairy & Pinnate & Indusiate \\
\hline 6 & $\begin{array}{l}\text { A. venustum } \\
\text { (Don) L. }\end{array}$ & 5200 & Hairy & Glabrous & Petiolate & $\begin{array}{l}\text { Pinnately } \\
\text { compound }\end{array}$ & Ndusiate \\
\hline 7 & $\begin{array}{l}\text { Asplenium } \\
\text { trichomanes (L) }\end{array}$ & 6240 & $\begin{array}{l}\text { Dark-brown to } \\
\text { dark-purple with } \\
\text { narrow brown } \\
\text { marginal wings }\end{array}$ & $\begin{array}{l}\text { Coriaceous, } \\
\text { glabrous }\end{array}$ & Glabrous & $\begin{array}{l}\text { Pinnate, linear } \\
\text { lanceolate }\end{array}$ & Indusiate \\
\hline 8 & $\begin{array}{l}\text { Ceterach } \\
\text { dalhousiae Hook }\end{array}$ & 4700 & & $\begin{array}{l}\text { Long, } \\
\text { glabrous, } \\
\text { lanceolate, }\end{array}$ & Glabrous & $\begin{array}{l}\text { Long, } \\
\text { glabrous, } \\
\text { lanceolate, } \\
\text { pinnately } \\
\text { compound }\end{array}$ & Exindusiate \\
\hline 9 & $\begin{array}{l}\text { C. officinarum } \\
\text { Willd }\end{array}$ & 4360 & Broad lanceolate & Glossy & glabrous & $\begin{array}{l}\text { Pinnate lamina } \\
\text { with trichomes }\end{array}$ & Exindusiate \\
\hline $\begin{array}{l}1 \\
0\end{array}$ & $\begin{array}{l}\text { Cheilanthus } \\
\text { albomarginata } \\
\text { (Clarke) }\end{array}$ & 6200 & Without scales & $\begin{array}{l}\text { Sub-coria- } \\
\text { ceous and } \\
\text { herbaceous }\end{array}$ & smooth & Pinnate, deltate & $\begin{array}{l}\text { Indusiate, } \\
\text { marginal }\end{array}$ \\
\hline
\end{tabular}

Maximum chlorophyll $b$ was found from gametophyte of the Cetarach officinarum which was followed by Adiantum caudatum and minimum chlorphyll $b$ was revealed from sporophyte of Adiantum incisum (Fig. 2). 


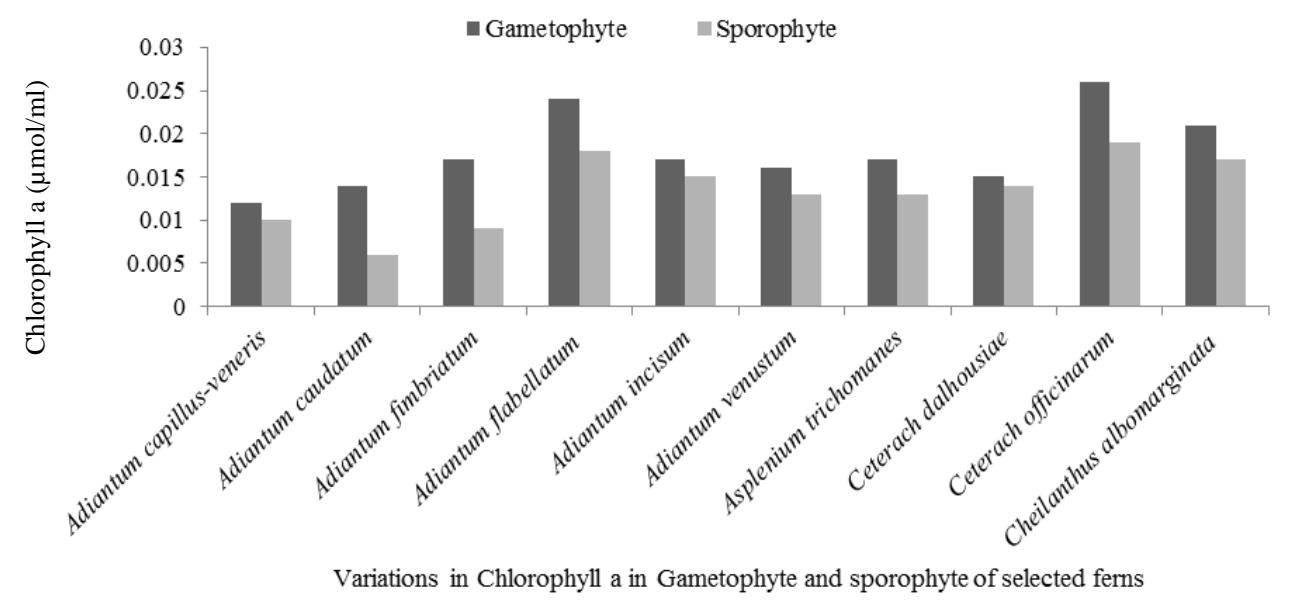

Fig. 1. Variations in Chlorophyll $a$ of gametophytes and sporophytes of ten fern species belonging to Filicales.

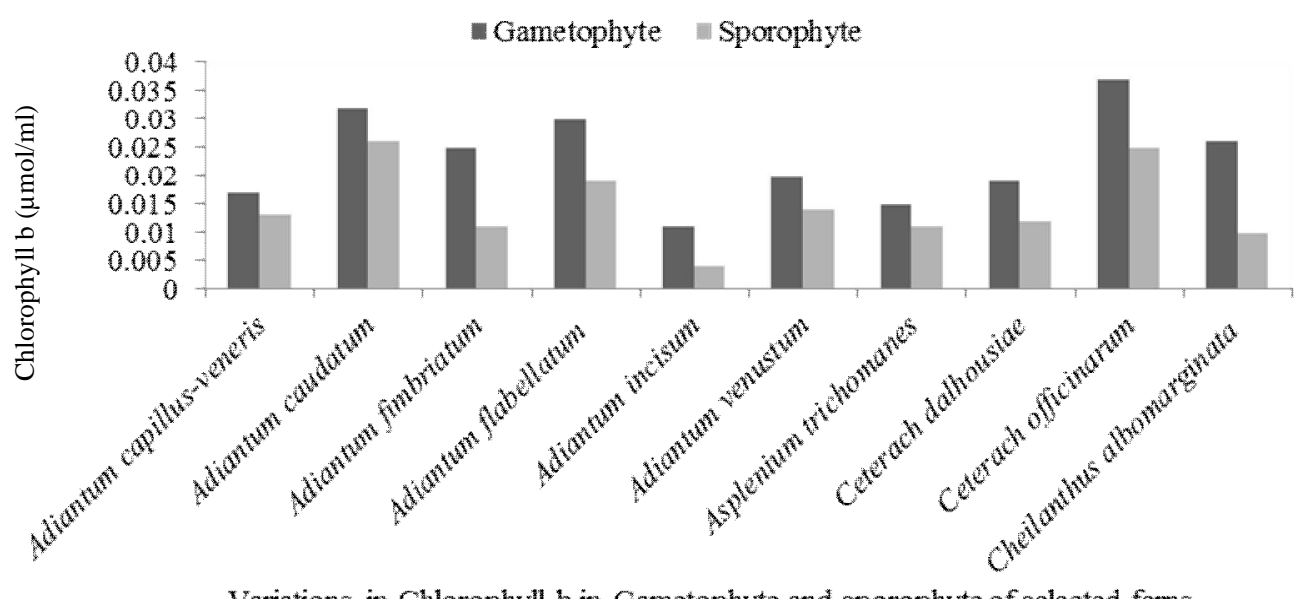

Fig. 2. Variations in chlorophyll $b$ of gametophytes and sporophytes of ten fern species belonging to Filicales.

Gametophyte of Cheilanthus albomarginata revealed maximum anthocyanin whereas minimum anthocyanin content was observed in sporophyte of Cetarach dalhousiae which significantly varied from anthocyanin values of all other samples under study (Fig. 3).

Maximum carotenoid content was found in gametophyte of which was Cheilanthus albomarginata non-significantly followed by Adiantum flabellatum and minimum carotenoid content was revealed from the sporophyte of Adiantum capillus-veneris (Fig. 4). Other species showed intermediate carotenoid contents but in all the species a decrease in pigments was observed from sporophyte compared to gametophyte. 


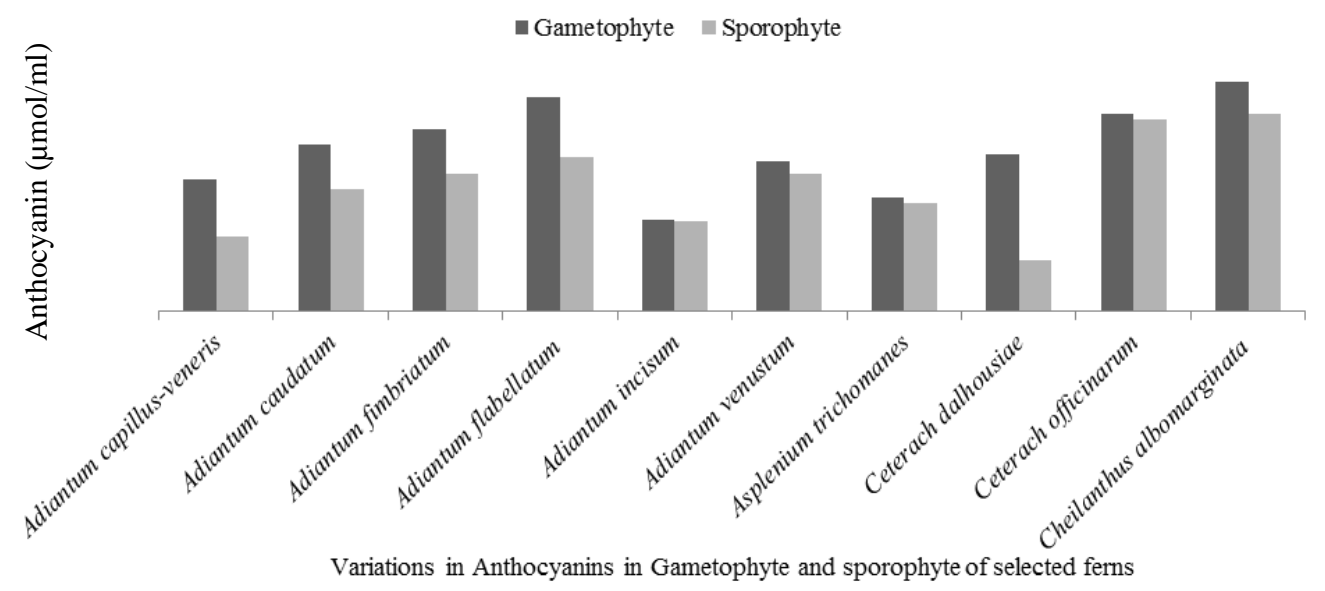

Fig. 3. Variations in anthocyanin of gametophytes and sporophytes of ten fern species belonging to Filicales.

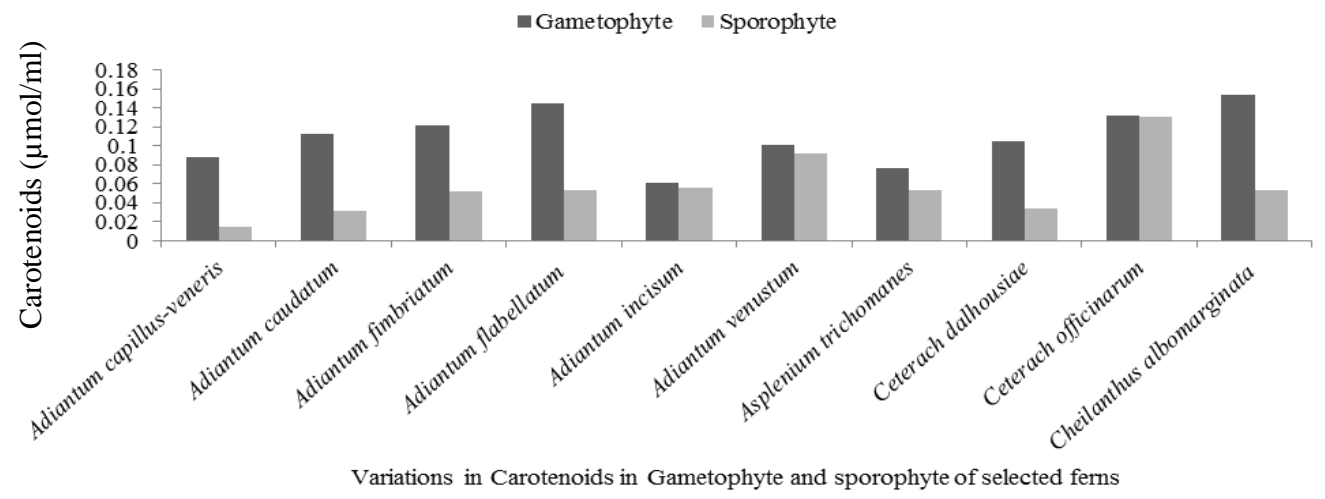

Fig. 4. Variations in carotenoids of gametophytes and sporophytes of ten fern species belonging to Filicales.

Many species are able to alter the composition of their photosynthetic apparatus to optimize photosynthesis for the light environment in which they are growing (Anderson et al. 1995). Although, the responses seen are complex with variations between species. In shade there was a tend to increase in the total amount of chlorophyll binding proteins relative to electron transport proteins and enzymes of the Calvin cycle (Yin and Johnson 2000). Amount of chlorophyll was higher in the shade ferns than the sun ferns (Nasrulhaq-Boyce and Mohamed 1987). The increase or decrease in chlorophylls depends on the available light. There was higher amount of chlorophylls and carotenoids in the terrestrial and epiphytic species than in the climbing species. Shaikh and Dongare (2008) showed that chlorophyll and carotenoids contents varied with microclimatic conditions in Adiantum philippense. Because of numerous factors concerned with nutrition, light and the plants sampled were growing under a variety of conditions which can influence chlorophyll content.

Carotenoids have two important roles in photosynthetic organisms. First, they act as accessory light harvesting pigments, effectively extending the range of light absorbed by the photosynthetic apparatus. Secondly, they perform an essential photoprotective role by quenching triplet state chlorophyll molecules and scavenging singlet oxygen and other toxic oxygen species 
formed within the chloroplast. Sharma and Sharma (1992) reported that the variability in carotenoids from species to species is independent of ecological conditions and morphology of the plant. Gena (2002) found no relationship in between carotenoids and chlorophylls and in between dry to moisture loving species of pteridophytes.

It may be inferred that significant variation in pigment contents of gametophyte and sporophyte generations of the same fern species is present. Moreover, climatic conditions and altitudinal variations were found to affect fern morphology and photosynthetic pigments in gametophyte and sporophyte generations.

\section{References}

Anderson JM, Chow WS and Park YI 1995. The grand design of photosynthesis: acclimation of the photosynthetic apparatus to environmental cues. Photosynthesis Res. 46: 129-139.

Arnon DI 1949. Copper enzymes in isolated chloroplasts. Polyphenoloxidase in Beta vulgaris. Plant Physiology 24: 1.

Gena C 2002. Pteridological researches in Rajasthan. Advances in Pteridology 154.

Nasrulhaq, Boyce A and Mohamed MH 1987. Photosynthetic and respiratory characteristics of Malayan sun and shade ferns. New Phytologist 105: 81-88.

Pryer KM, Schneider H, Smith AR, Cranfill R, Wolf PG, Hunt JS and Sipes SD 2001. Horsetails and ferns are a monophyletic group and the closest living relatives to seed plants. Nature 409: 618-622.

Shaikh S and Dongare M 2008. Analysis of photosynthesis pigments in Adiantum lunulatum Burm. At different localities of Sindhudurg District (Maharastra), Indian Fern J. 25: 83-86.

Sharma A and Sharma B 1992. Phytochemistry of Rajasthan ferns: A study of flavonoids. Indian Fern J. 9: 83-86.

Taiz L and Zeiger E 2002. Plant Physiology. 3rd edition, Sinauer Associates, Inc., Publishers, Sunderland, 67-86.

Wada M 2007. The fern as a model system to study photomorphogenesis. J. Plant Res. 120: 3-16.

Watkins JE, Mack MK and Mulkey SS 2007. Gametophyte ecology and demography of epiphytic and terrestrial tropical ferns. American J. Bot. 94: 701-708.

Wild M and D Gagnon 2005. Does lack of available suitable habitat explain the patchy distributions of rare calcicole fern species? Ecography 28: 191-196.

Yin ZH and Johnson GN 2000. Photosynthetic acclimation of higher plants to growth in fluctuating light environments. Photosynthesis Res. 63: 97-107. 